\title{
Water Intoxication Resulting in Ventricular Arrythmias
}

\author{
Ventriküler Aritmilere Neden Olan Su Zehirlenmesi
}

\author{
Pınar TÜRKER BAYIR, Burcu DEMIRKAN, Serkan DUYULER, Ümit GÜRAY, Halil Lütfi KISACIK \\ Department of Cardiology, Turkiye Yuksek Ihtisas Hospital, Ankara
}

\section{SUMMARY}

Water intoxication, defined as excessive water ingestion within a short period of time, may cause severe neurologic and cardiac symptoms. This condition is commonly seen in psychiatric patients, however the ingestion of excessive water is an infrequent method for attempting suicide. In this case report we present a 51-year-old woman with ventricular fibrillation due to electrolyte imbalance caused by excessive water ingestion during a suicide attempt. The patient was admitted to our emergency clinic with altered consciousness and agitation. She was hypertensive and neurological examination revealed no lateralizing signs. Ventricular arrhythmias, cardiopulmonary arrest and tonic-clonic seizure were observed during hospitalization. Blood chemistry showed hyponatremia and hypokalemia relevant to the patient's history of ingestion of 12 liters of water in 4 hours time. After electrolyte disturbances were corrected, ventricular arrhythmias and seizure did not recur. The patient was referred for psychiatric evaluation and was discharged with antidepressive medication. Although water intoxication is well described in psychiatric disorders such as schizophrenia, it has not been previously reported in depressive patients with suicidal thought. Awareness of the clinical presentation of this rare situation may prevent potentially fatal complications.

Key words: Suicide; ventricular arrythmia; water intoxication.

\section{ÖZET}

Ağız yoluyla kısa sürede aşırı su alımı ciddi nörolojik ve kardiyak semptomlara yol açabilir ve su zehirlenmesi olarak adlandırılır. Bu durum psikiyatrik hastalarda sıklıkla görülmektedir ancak intihar amaçlı aşırı su alımı oldukça enderdir. Bu olgu sunumunda intihar amaçlı aşırı su alımının yol açtığı elektrolit dengesizliğine bağIı ventriküler fibrilasyon gelişen 51 yaşındaki hastayı sunuyoruz. Hasta acil kliniğimize bilinç değişikliği ve ajitasyon ile başvurdu. Hasta hipertansifti ve nörolojik muayenesinde lateralizasyon bulgusu yoktu. Hastanede takibi esnasında ventriküler aritmi kardiyopulmoner arrest ve tonik klonik nöbet gözlendi. Kan biyokimyasında hastanın 4 saat içerisinde 12 litre su içmesiyle uyumlu olan hiponatremi ve hipokalemi mevcuttu. Elektrolit bozukluğunun düzeltilmesinden sonra ventriküler aritmi ve nöbet tekrarlamadı. Hasta psikiyatrik değerlendirmeye yönlendirildi ve antidepresan tedavi ile taburcu edildi. Su zehirlenmesi şizofreni gibi psikiyatrik bozukluklarda iyi bilinse de intihar düşüncesi olan depresif hastalarda daha önce bildirilmemiştir. Bu nadir durumun klinik sunumuna olan farkındalık potansiyel olarak ölümcül seyredebilen komplikasyonları önleyebilir.

Anahtar sözcükler: Özkıyım; ventriküler aritmi; su zehirlenmesi.

\section{Introduction}

Excessive water ingestion in a short period of time may cause severe cardiac and neurologic symptoms. This condition, known as 'water intoxication', is generally encountered in psychiatric illnesses such as schizophrenia. ${ }^{[1,2]}$ Water in- toxication is also reported in child abuse cases, in urology patients after uroflowmetry evaluation, and occasionally in otherwise healthy individuals. ${ }^{[3,4]}$ However, excessive water ingestion with suicidal purpose is an extremely rare clinical presentation. Here, a female patient who attempted suicide

Submitted (Geliş tarihi): 11.03.2012 Accepted (Kabul tarihi): 14.05 .2012

Correspondence (iletişim): Dr. Pınar Türker Bayır. Gayret Mah. A.O.Ç Toki Bloklar Ck 1 No: 42, Yenimahalle, Ankara, Turkey

e-mail (e-posta): turkerpinar1982@hotmail.com 
by excessive water ingestion over a short period of time is presented with clinical and laboratory findings.

\section{Case Report}

A 51-year-old female patient was admitted to our emergency clinic with altered consciousness and agitation. She had a complaint of severe headache before alteration of consciousness. On admission her her body temperature was $36.7^{\circ} \mathrm{C}$, blood pressure was $240 / 140 \mathrm{mmHg}$, pulse rate was 84 beats per minute, and respiratory rate was 24 per minute. On physical examination, mucosal membranes were wet and normal in color. Auscultation revealed a loud S2 and with no murmur and the lungs were clear. Neurological examination revealed that she was confused and disoriented. She was not cooperating during examination. Pupillas were isocoric and no lateralizing sign was observed. Deep tendon reflexes were mildly depressed in a generalized manner. During initial examination, the patient went into cardiovascular arrest and observed ventricular fibrillation was successfully terminated with defibrillation (Fig. 1). Electrocardiogram revealed sinus rhythm with a CQT interval of 510 milliseconds and prominent $\mathrm{U}$ wave. Patient was intubated since respiration was depressed. The patient's family claimed that patient had no known physical or mental illness except hypertension and she was taking olmesartan $20 \mathrm{mg}$ daily. To the best of their knowledge, she was not taking any other medication or exposed to toxic substances. She had no known suicide attemt, but they also claimed she was under emotional stress and she had ingested several liters of tap water in a short period of time. Blood chemistries revealed sodium was 107 $\mathrm{mmol} / \mathrm{l}$, potassium was $2.7 \mathrm{mmol} / \mathrm{l}$, calcium was $2.0 \mathrm{mmol} / \mathrm{l}$, magnesium was $1.25 \mathrm{meq} / \mathrm{l}$ and $\mathrm{pH}$ was 7.28 . Complete blood count, urea, creatinine, alanine aminotransferase and aspartate aminotranferase levels were within normal ranges. Although neurological findings and hypertension were mimicking hypertensive encephalopathy, the patient's history, electrolyte levels, and clinical manifestations were consistent with water intoxication. The patient was referred to the intensive care unit. Intravenous magnesium ( $1 \mathrm{gr}$ ) slow bolus was applied and $3 \% \mathrm{NaCl}(0.5 \mathrm{ml} / \mathrm{kg} /$ hour $)$ and $\mathrm{KCl}$ (6 meq/hour) infusion was initiated immediately to correct the electrolyte imbalance. Meanwhile the patient's cardiac rhythm deteriorated into torsade des pointes, causing hemodynamic compromise which was corrected successfully by 100 Joule direct current cardioversion. In the second hour of hospitalization, the patient developed tonic clonic seizure which was terminated with $10 \mathrm{mg}$ intravenous diazepam administration. A consultant neurologist concluded that this seizure was secondary to electrolyte disturbance owing to patient's neurologic examination and normal cranial computed tomography findings. In the 24th hour after electrolyte replacement, blood chemistry revealed sodium was 128 $\mathrm{mmol} / \mathrm{l}$ and potassium was $4.1 \mathrm{mmol} / \mathrm{l}$. During follow up, the patient's level of consciousness normalized and she was extubated. Blood electrolytes were stable and arrhythmias did not recur during monitorization. Patient confirmed that she had ingested 12 liters of tap water in 4 hours time with suicidal purpose. Consultant psychiatrist diagnosed major depression and patient was discharged with anti-depressive medication.

\section{Discussion}

Excessive water intake in a short period of time may result in severe deteriorations in electrolyte balance leading to cardiac and neurologic symptoms. ${ }^{[1,2]}$ This rare entity known as 'water intoxication' was first described by Barahal in $1938^{[5]}$ This disorder presents a variety of clinical signs and symptoms which may be challenging for clinician who is not aware of this rare situation. In the literature, the majority of water intoxication cases are described in the psychiatric disorders, particularly in schizophrenia. Polydypsia with unknown etiology, which is not infrequent in schizophrenic patients, may lead to water intoxication. ${ }^{[6]}$ latrogenic water intoxication may be secondary to excessive irrigation during uroflowmetry, transurethral prostate resection or gastric lavage.$^{[7]}$ Forced water intoxication was also reported in a fa-

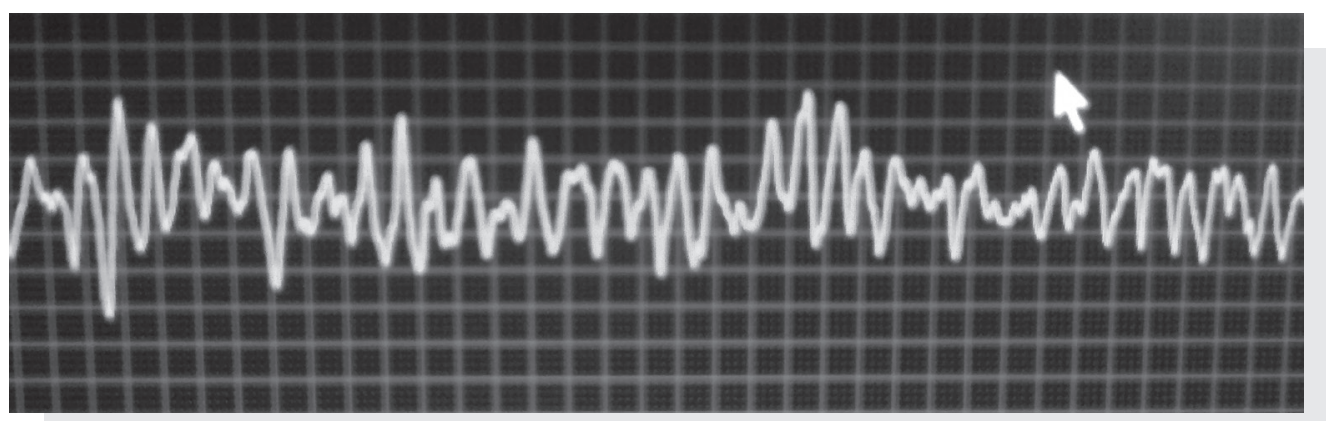

Figure 1. Monitor recording of ventricular fibrillation observed during patient's examination in the emergency room. 
tal child abuse case. ${ }^{[3]}$ Moreover, water intoxication may be encountered in individuals after marathon runs, heat strokes or during over-hydration of patients with gastroenteritis or urinary tract infection ${ }^{[1,3,4]}$ Water intoxication as a suicide method is a very extraordinary situation.

Excessive water intake primarily affects sodium concentration in body fluids. Symptoms usually develop at serum sodium concentrations under $120 \mathrm{mmol} / \mathrm{l}$ secondary to dilutional hyponatremia. Initial symptoms are mild nausea and vomiting. Severe symptoms such as confusion, agitation, sleepiness, coma and epileptic seizures develop at serum concentrations under $115 \mathrm{mmol} / \mathrm{I}^{[4]}$ Hypokalemia promotes arrhythmias by decreasing $\mathrm{K}^{+}$conductance through voltage-gated channels, decreasing the hyperpolarization effect of the ion during the repolarization phase in cardiac tissue. A partly depolarized membrane potential promotes automaticity, leading to ventricular arrhythmias. Hypokalemia also provokes changes in ST-segment, decrease in T wave amplitude, $\mathrm{T}$ wave inversion, elongation in QTsegment and prominent $U$ wave. Hypokalemia also causes ventricular fibrillation and respiratory depression. ${ }^{[8,9]}$ Acute severe electrolyte imbalance leading to fatal arrhythmia and neurologic disturbances is the main cause of death in water intoxication. In our case we observed agitation, confusion, epileptic seizure secondary to dilutional hyponatremia and ventricular arrhythmias caused by hypokalemia. These neurologic and cardiac findings totally reverted after correction of electrolyte imbalance. To the best of our knowledge, this is the first case of ingestion of excess water with suicidal purpose resulting in water intoxication.

In conclusion, excessive water ingestion over a short period of time may result water intoxication. This clinical presentation is common in schizophrenia. However it may be seen in depressive patients with suicidal thought as we report in this case. Electrolyte imbalance secondary to water intoxication may cause severe neurologic and cardiac disturbances. Early recognition of this rare situation may avoid potentially fatal complications.

\section{Conflict of Interest}

The authors declare that there is no potential conflicts of interest.

\section{References}

1. Hiramatsu R, Takeshita A, Taguchi M, Takeuchi Y. Symptomatic hyponatremia after voluntary excessive water ingestion in a patient without psychiatric problems. Endocr J 2007;54:643-5.

2. Santos-Soares PC, Bacellar A, Povoas HP, Oliveira-Filho J, Filgueiras NM, Brito AF. Excessive water ingestion and repeated seizures: the domino effect. Arq Neuropsiquiatr 2008;66:552-3.

3. Arieff Al, Kronlund BA. Fatal child abuse by forced water intoxication. Pediatrics 1999;103:1292-5.

4. Farrell DJ, Bower L. Fatal water intoxication. J Clin Pathol 2003;56:803-4.

5. Barahal HS. Water intoxication in a mental case. Psychiatr Q 1938;12:767-71.

6. Vishwajeet $S$, Aneesh S. Water intoxication leading to hyponatremia and seizures: a rare complication of uroflowmetry. Int Urol Nephrol 2005;37:275-6.

7. Hayashi T, Ishida Y, Miyashita T, Kiyokawa H, Kimura A, Kondo T. Fatal water intoxication in a schizophrenic patient--an autopsy case. J Clin Forensic Med 2005;12:157-9.

8. Boetzkes S, Van Hoeck K, Verbrugghe W, Ramet J, Wojciechowski M, Jorens PG. Two unusual pediatric cases of dilutional hyponatremia. Pediatr Emerg Care 2010;26:503-5.

9. Kluger MT, Szekely SM, Singleton RJ, Helps SC. Crisis management during anaesthesia: water intoxication. Qual Saf Health Care 2005; 14:23. 